\section{To: (Receiving Organization)}

Distribution

5. Proj./Prog./Dept./Div.:

/K6178/PFP ENGINEERING/15500

8. Originator Remarks:

SYSTEM DESIGN DESCRIPTION DOCUMENT FOR THE SAND, SLAG, AND CRUCIBLE CEMENTATION PROCESS AT THE PFP
11. Receiver Remarks:
11A. Design Basel ine Document?
[] Yes
[X] No

4. Related EDT No.:

$N / A$

7. Purchase Order No.:

$N / A$

9. Equip./Component No.: N/A

10. System/Bldg./Facility: 234-5Z, Room 235B.

12. Major Assm. Dwg. No.: $N / A$

13. Permit/Permit Application No.: $N / A$

14. Required Response Date: $N / A$

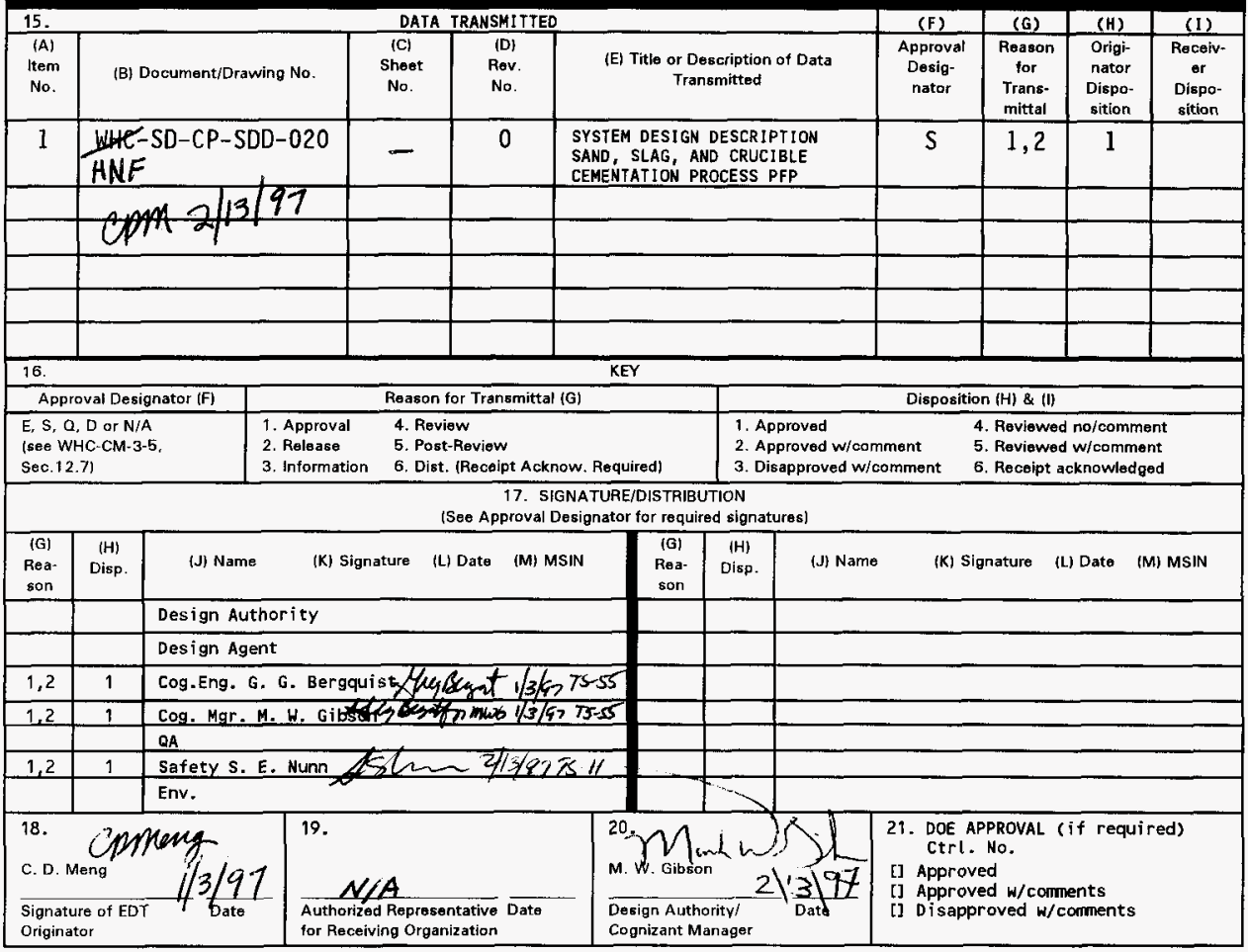

BD-7400-172-2 (05/96) GEF097 


\title{
SYSTEM DESIGN DESCRIPTION SAND, SLAG, AND CRUCIBLE CEMENTATION PROCESS PFP
}

\author{
G. G. Bergquist and C. D. Meng \\ B \& W Hanford Company, Richland, WA 99352 \\ U.S. Department of Energy Contract DE-AC06-96RL13200

$\begin{array}{lll}\text { EDT/ECN: } & 609914 & \text { UC: } 2050 \\ \text { Org Code: } & 15530 & \text { Charge Code: } \\ \text { B\&R Code: } & \text { EW7003000 } & \text { Tota1 Pages: } 17\end{array}$

Key Words: SDD, Sand, STag, and Crucible, Cementation

Abstract: The SDD documents the Structures, Systems, and Components that establish the facility Safety Envelope for the Cementation of SS\&C.

Eurotherm is a registered trademark of Eurotherm PLC, Horsham, West Sussex, United Kingdom. Hobart mixers is a registered trademark of Premark FEG Corporation, Troy, OH. Neslab is a registered trademark of NESLAB INSTRUMENTS, INC., Newington, NH. Omega is a registered trademark of Omega Eningeering, Inc., Stamford, CT. Square D is a registered trademark of Square D Company, Palatine, IL. General Electric is a registered trademark of Genera1 Electric Corporation, Schenectady, NY.

TRADEMARK DISCLAIMER. Reference herein to any specific commercial product, process, or service by trade name, trademark, manufacturer, or otherwise, does not necessarily const itute or imply its endorsement, recomendation, or favoring by the United States Government or any agency thereof or its contractors or subcontractors.

Printed in the United States of America. To obtain copies of this document, contact: LMSI Document Control Services, P.0. Box 950, Mailstop H6-08, Richland WA 99352, Phone (509) 376-1418; Fax (509) 376-4989.
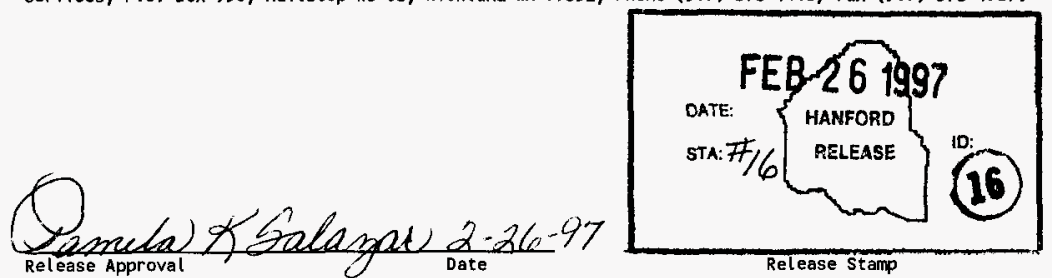

Approved for Public Release 
TABLE OF CONTENTS

1.0 PURPOSE . . . . . . . . . . . . . . . . 3

2.0 SUMMARY . . . . . . . . . . . . . . . . 3

3.0 FUNCTIONS AND DESIGN REQUIREMENTS . . . . . . . . . . . . . 4

3.1 PROCESS REQUIREMENTS ................. . . 4

3.2 INTERFACES . . . . . . . . . . . . . . . 4

3.2 .1 Power . . . . . . . . . . . . . . . 5

3.2 .2 Control . . . . . . . . . . . . 5

3.2 .3 Mixer Bowl Reactor Temperature . . . . . . . 5

4.0 SAFETY INTERLOCKS, SET POINTS, AND ALARMS . . . . . . . . 5

4.1 SAFETY INTERLOCKS . . . . . . . . . . . . . 5

4.2 SET POINTS/RANGES . . . . . . . . . . . . . 5

4.3 ALARM RESPONSE .................. . . . 6

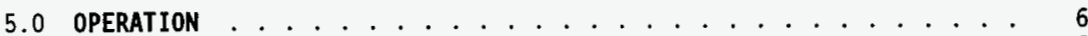

5.1 OPERATING PROCEDURES . . . . . . . . . . . . . . . 6

5.2 OPERATING SPECIFICATIONS DOCUMENT . . . . . . . . . . . 6

5.3 PROCESS FLOWSHEET DOCUMENT . . . . . . . . . . 6

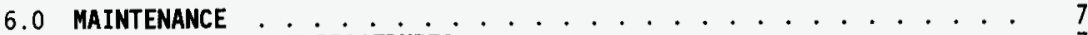

6.1 MAINTENANCE PROCEDURES ................... 7

6.2 VENDOR INFORMATION FILES . . . . . . . . . . . 7

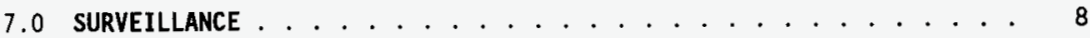

8.0 SAFETY . . . . . . . . . . . . . . . . . . . 8

8.1 FIRE SAFETY . . . . . . . . . . . . . . . . 10

8.1 .1 Glovebox Fire . . . . . . . . . . . . . . . 10

8.1 .2 Combustible Material . . . . . . . . . . . . . 10

8.1.3 Flammability of off-Gas . . . . . . . . . . . 10

8.2 CRITICALITY . . . . . . . . . . . . . . . . . 10

8.3 RADIATION SAFETY . . . . . . . . . . . . . . 11

8.4 INDUSTRIAL SAFETY . . . . . . . . . . . . . Il

8.4 .1 Foaming ................ . . 11

8.4 .2 Jaw Crusher ................. 12

8.4.3 Can Opener . . . . . . . . . . . . . 12

9.0 EQUIPMENT SAFETY CLASS ANALYSIS . . . . . . . . . . . . . . 12

9.1 HA-2OMB OFF-GAS SYSTEM . . . . . . . . . . . . . 12

9.2 MIXER REACTOR \#I HIGH TEMPERATURE SHUTOFF INTERLOCK . . . . 13

10.0 REFERENCES . . . . . . . . . . . . . . . . . 14

APPENDIX A SYSTEM DRANING LIST . . . . . . . . . . . . . . . 15

APPENDIX B MASTER COMPONENT INDEX LIST . . . . . . . . . . . . 16 


\subsection{PURPOSE}

The purpose of this document is to provide a system design description (SDD) and design basis for the Plutonium Finishing Plant (PFP) Sand, Slag, and crucible (SS\&C) Cementation process. The chief objective of the SDD is to document the Structures, Systems, and Components (SSCS) that establish and maintain the facility Safety Envelope necessary for normal safe operation of the facility; as identified in the Final Safety Analysis Report (FSAR), the Operational Safety Requirements (OSRs), and Safety Assessment Documents (SADs). This safety equipment documentation should satisfy guidelines for the SDD given in WHC-SD-CP-TI-181, Criteria for Identification and Control of Equipment Necessary for Preservation of the Safety Envelope and Safe Operation of PFP.

The basis for operational, alarm response, maintenance, and survei11ance procedures are also identified and justified in this document. This document and its appendices address the following elements of the PFP SS\&C Cementation Process:

- Functional and design requirements

- Design description

- Safety Envelope Analysis

- Safety Equipment Class

- Operational, maintenance, and surveillance procedures

\subsection{SUMMARY}

The SS\&C Cementation Process is designed to immobilize Plutonium (Pu) bearing Sand, Slag, \& Crucible residues from the RMC button line operations in cement. The SS\&C is currently stored in the vaults at the PFP. Stabilizing this material will facilitate disposal of the material as TRU waste and reduce worker exposure.

The SS\&C material is cemented in glovebox HA-2OMB (Room 235B) of the 234-5Z building. Cemented material, after curing, will be sealed out of a sealout port on the HA-2OMB glovebox or the HA-28 conveyor (the sealout port may have a permanent containment tent around $i t)$. The cemented cans will be transferred to Transuranic (TRU) waste drums. The TRU waste drums are sent to the Transuranic Waste Storage and Assay Facility (TRUSAF) and later to the Waste Isolation Pilot Plant (WIPP).

There is no equipment defined as Safety $\mathrm{Class}$ or Safety Significant for this process. No OSRS are necessary for the PFP SS\&C Cementation Process. 
HNF-SD-CP-SDD-020

Rev. 0

\subsection{FUNCTIONS AND DESIGN REQUIREMENTS}

SS\&C to be cemented is staged for preparation in the HA-2OMB glovebox. It is opened, weighed, divided as needed in HA-20MB to meet the unreacted calcium limits, and a measured amount of SS\&C is processed through a size reduction unit. The size reduction unit is a jaw crusher with an opening shimmed to approximately $1 / 16$ inch so the crushed material passes through 8 mesh screen. The feed batch is then transferred to the reaction mixing bow 1 via the auger in HA-20MB and mixed with chilled water to react residual calcium metal. This step enables control of the exothermic reaction temperatures and hydrogen generation of calcium metal with water. Following the calcium oxidation, the reacted mixture of SS\&C solids and water are mixed with cement to form a cement matrix. When the cement is cured, it is sealed out, packaged in a TRU drum, and shipped to TRUSAF.

\subsection{PROCESS REQUIREMENTS}

Process requirements for the SS\&C Cementation process specify what types of material may be processed, process conditions, and what specifications the finished product must meet. An important feed criterion is the type of feed (SS\&C). Important finished product criterion is no excess water on top of the cured cement. Process requirements for this system are defined and explained in PFD-Z-200-011, Sand, Slaq, and Crucible Cementation Process Flowsheet, and 0SD-Z-184-00039 Sand, S7ag, and Crucible Cementation Process PFP.

\subsection{INTERFACES}

Feed materials (SS\&C) will be transferred from the $2736-Z$ vaults and Room 192-B to HA-20MB glovebox twice a week during normal operations. Glovebox HA-2OMB and Room 235B will be used as a staging area for both feed and product. Cemented material will be transferred to a TRU drum and the drum sent to TRUSAF. Off-gas streams from the HA-2OMB glovebox are filtered by 2 stages of HEPA filters prior to discharging to the 291-Z stack through the E-4 ventilation system.

Gases enter the HA-20MB glovebox through several systems. HA-20MB has an inlet stream consisting of the former 'dry' air supply (Note: The dry air system no longer supplies dry air, air is supplied at atmospheric humidity). HA-20MB is also connected to the HA-28 conveyor glovebox which allows air to flow to this glovebox.

Air will exit the HA-20MB glovebox through a local HEPA filter before entering the E-4 exhaust system. 
HNF-SD-CP-SDD-020

Rev. 0

\subsubsection{Power}

Power (120 VAC) is supplied from CB-1 to glovebox HA-20MB through box PBI on the end of the glovebox. Conduit runs to the ARS-2 for the electrical equipment in the glovebox.

\subsubsection{Control}

Controls (on/off switches) for the cementation process are located on the outside of glovebox HA-20MB. The high temperature alarms for the cementation process are available on an alarm panel located on the North wall of Room 235B.

\subsubsection{Mixer Bowl Reactor Temperature}

The Mixer Bowl Reactor temperature is measured by a thermocouple (TC) which provides input to a high temperature alarm switch (TAS). To prevent water loss to the glovebox and prevent the water from boiling TAS-2OMB-1 is interlocked to remove power from the SS\&C feed auger if the temperature exceeds a high set point $\left(80^{\circ} \mathrm{C}\right)$. A redundant high high temperature limit is set at $90^{\circ} \mathrm{C}$ (TAS-20MB-2) in the event the $80^{\circ} \mathrm{C}$ interlock were to fail.

When the set point temperature is exceeded the feed auger interlock actuates and an audible alarm sounds.

\subsection{SAFETY INTERLOCKS, SET POINTS, AND ALARMS}

\subsection{SAFETY INTERLOCKS}

The safety interlocks control power to feed auger. Power will be removed from the feed auger when either of the following conditions occur:

1. If the temperature exceeds the high set point at $80^{\circ} \mathrm{C}$.

2. If the temperature exceeds the high high temperature set point at $90^{\circ} \mathrm{C}$.

\subsection{SET POINTS/RANGES}

Set points and ranges for mixer bowl reactor temperatures, feed auger rate, alarms, etc. have been out1ined in WHC-OSD-Z-184-00039, the operating specifications document (OSD) for the Sand, Slag \& Crucible Cementation Process. The OSD also identifies off-standard conditions and recovery actions. Specific set points and ranges will not be stated here in order to avoid inconsistencies between this document and the OSD. 


\subsection{ALARM RESPONSE}

Alarms associated with cementation process will display on an alarm display on the north wall of Room 235B. Alarm response operator actions for the SS\&C Cementation process are documented in 20-160-060.

\subsection{OPERATION}

\subsection{OPERATING PROCEDURES}

- 20-160-060, Stabilization Cementation. This procedure provides instructions for stabilizing SS\&C in a cement matrix.

\subsection{OPERATING SPECIFICATIONS DOCUNENT}

- WHC-0SD-Z-184-00039, Sand, Slag, \& Crucible Cementation Process PFP. This document contains specification limits for feed items, auger feed rates, feed particle size, weight percent Plutonium in stabilized material, process water chiller starting temperatures, charge size, and cement requirements. Information detailing detection/control of process variables and recovery actions are also given.

\subsection{PROCESS FLOWSHEET DOCUMENT}

- PFD-Z-200-011, Sand, Slag, and Crucible Cementation Process Flow Document. The Process Flowsheet Document (PFD) contains detailed information on process parameters and design. It includes equipment description, process technology, control schemes and set points, off-standard conditions, and safety concerns. 


\subsection{MAINTENANCE}

\subsection{MAINTENANCE PROCEDURES}

Calibration maintenance activities are initiated using the PMS system and PSCP and other general calibration procedures. Listed below are specific procedures used in the SS\&C Cementation process.

\begin{tabular}{||l|l|l|l||}
\hline Procedure Number & Description & $\begin{array}{l}\text { Associated } \\
\text { Equipment }\end{array}$ & Loop Number \\
\hline \hline ZCP-6-001 & $\begin{array}{l}\text { Eurotherm Model 93 } \\
\text { Temperature Alarm Switch } \\
\text { Calibration }\end{array}$ & TAS-20MB-1 & 2Z-6680 \\
\hline ZCP-6-001 & $\begin{array}{l}\text { Eurotherm Model 93 } \\
\text { Temperature A1 arm Switch } \\
\text { Calibration }\end{array}$ & TAS-20MB-2 & 2Z-6681 \\
\hline
\end{tabular}

\subsection{VENDOR INFORMATION FILES}

The vendor information (VI) file is compiled to address all of the components installed for Cementation of plutonium bearing SS\&C materials in glovebox HA-20MB. The VI file is:

VI Number

22682
Description

Hobart Mode1 N50 Mixer Item 3

Neslab CFT Series (R134a) Recirculating Chiller Item 4 


\subsection{SURVEILLANCE}

Surveillance of equipment is controlled and monitored through the Preventative Maintenance System (PMS). The PMS is a large database which tracks when equipment surveillance needs to occur and what information needs to be recorded. This database also contains historical data (past calibration or functional checks) for the equipment. The following table lists all cementation equipment in the PMS database and the surveillance interval.

\begin{tabular}{|c|c|c|c|}
\hline $\begin{array}{c}\text { PMS } \\
\text { ID }\end{array}$ & $\begin{array}{c}\text { INSIRUMENT } \\
\text { IDENTIFICATION }\end{array}$ & FUNCTION & $\begin{array}{c}\text { VERIFICATION } \\
\text { INTERVAL }\end{array}$ \\
\hline $22-6680$ & TAS-2OMB-1 & TEMPERATURE ALARM & 12 MONTHS \\
\hline $2 Z-6681$ & IAS-20MB-2 & TEMPERATURE ALARM & 12 MONTHS \\
\hline
\end{tabular}

\subsection{SAFETY}

The principle hazards associated with glovebox HA-20MB operations are fire, criticality, and radiation. The following section describes the potential hazards associated with cementation stabilization. In addition, glovebox HA-20MB was analyzed for a deflagration of hydrogen gas from the reaction of calcium metal with water. The analysis determined that the deflagration was bounded by an existing safety analysis for glovebox MT-5.

There are no OSRs associated with the PFP SS\&C Cementation Process. The equipment installed by the SS\&C Cementation Process was also determined to be "other equipment important to safety".

Worker safety and accident analys is are documented in the MT-5 Glovebox analysis. The two bounding accident scenarios for the MT-5 system, and thus the SS\&C Cementation Process, are: a fire within the glovebox, and the rapid decomposition of tributyl phosphate (TBP) leading to the formation of combustible gases and deflagration of the gas.

Calculated consequences for glovebox fires were found to be within risk acceptance guidelines. The rapid decomposition of TBP leading to the formation of combustible gases was shown to be an incredible event. The probability of a seismically induced deflagration in glovebox MT-5 resulting from a design basis earthquake (DBE) and a small earthquake were quantified and shown to be incredible events.

For further detail on safety criteria, see WHC-SD-CP-SAR-021, PFP Final Safety Analysis Report and WHC-SD-CP-FHA-004, PFP Fire Hazards Analysis (FHA). 
The following analysis was performed and documented in the USQ evaluation PFP-96-007. Calculations were performed using SS\&C containing 20 wt\% unreacted calcium metal. This conservative assumption exceeds the $9 \%$ calcium by weight given in the flowsheet values for RMC residues. The heat of combustion of the butene in the MT-5 scenario was compared to the heat of combustion of hydrogen.

The USQ comparison of the HA-2OMB operations to MT-5/HC-21C operations shows that:

1) the fire scenario in MT-5/HC-21C (butene gas) is bounding for HA$20 \mathrm{MB}$ (hydrogen gas) due to the 500 grams at risk in $\mathrm{HA}-20 \mathrm{MB}$, opposed to $2 \mathrm{kgs}$ in MT-5 or the $5 \mathrm{kgs}$ in $\mathrm{HC}-21 \mathrm{C}$,

2) the deflagration scenario in MT-5/HC-21C is bounding for HA-2OMB as the material at risk is no more than 180 grams per charge, 500 grams total in glovebox; as compared to 1000 grams in MT-5 and 500 grams in $\mathrm{HC}-21 \mathrm{C}$. Also bounding this scenario is the 1.2 grams released to the room in the Radioisotope - Bearing Powder Spills, a probability 1 event, and

3) the Seismically Induced Deflagration in Glovebox MT-5/HC-21C is bounding for $\mathrm{HA-20MB}$. The release of $0.36 \mathrm{grams}$ comes from an analysis of a 500 grams plutonium item in Glovebox MT-5 spilling onto the glovebox floor and being dispersed by the resulting deflagration. By limiting the maximum plutonium in any unreacted can in HA-2OMB to 100 grams plutonium, the same release would be equivalent to 8500 (five times the $1700 \mathrm{~g}$ in each can) grams of SS\&C reacting in $\mathrm{HA}-20 \mathrm{MB}$.

The results of this analysis are consistent with the PFP Fire Hazards Analysis (FHA). The PFP FHA requires automatic fire detection and suppression in an active glovebox which has combustible material, plastic windows, and is connected to other gloveboxes. Glovebox HA-20MB has hydrogen gas present during the reaction step of cementation, plastic windows, and it is connected to a conveyor glovebox. Glovebox HA-20MB has automatic fire detection and dry chemical fire suppression. 
HNF-SD-CP-SDD-020

Rev. 0

\subsection{FIRE SAFETY}

\subsubsection{Glovebox Fire}

The presence of flammable gas (hydrogen) is a factor which could lead to a glovebox fire in HA-20MB. Glovebox HA-20MB is equipped with an automatic dry chemical fire suppression system.

\subsubsection{Combustible Material}

In practicing good fire prevention, combustible materials must be kept to a minimum within the glovebox.

\subsubsection{Flammability of Off-Gas}

The process reacts the residual calcium in SS\&C ( $9 \%$ by weight based on flowsheet values for RMC) with excess water. There is a concern for hydrogen generation when reacting calcium with water. To prevent the accumulation of flammable levels of gas, the addition of the SS\&C to the water will occur at a controlled rate. The process reacts the SS\&C at a maximum rate of 50 grams/minute. Calculations (WHC-SD-CP-OCD-041 Attachment 5) showed that hydrogen was generated at a rate of $0.0467 \mathrm{~L} / \mathrm{sec}$ above the mixer bowl. The volume of free space above the mixer bowl is 3.4 liters, assuming the mixer bowl is at the specified operational volume of 1.4 liters. Further, four percent of mixer bowl volume free space is $0.14 \mathrm{~L}$. The hydrogen generated at any one instant is less that the flammability point of hydrogen at four percent in a confined space. The calculations were performed assuming stagnate air within the glovebox. This calculation is very conservative as water vapor in the head space above the bowl dilutes the $\mathrm{H}_{2}$ even further but was not included in the calculations. The glovebox air flow dilutes the hydrogen gas further as it is removed so a flammable concentration will not form above the bowl or in the off-gas equipment (piping, etc.).

\subsection{CRITICALITY}

Since plutonium is a fissile material, measures are taken to assure prevention of conditions which could lead to a criticality incident. A criticality prevention specification (CPS-Z-165-80634) has been prepared for glovebox HA-20MB to accommodate the SS\&C Cementation process. Limits on plutonium quantities, container volume, stacking containers, and material spacings are specified in the CPS and shall be strictly adhered to during operations. A Criticality Safety Evaluation Report (WHC-SD-SQA-CSA-513) has also been prepared for cementation in the HA-20MB glovebox. 


\subsection{RADIATION SAFETY}

During the design and operational preparations for the cementation process, ALARA considerations were instituted to decrease the expected dose. A summary of these actions are given below:

Minimize Operator's Time in Gloves

- Feed auger is used instead of hand feed.

- Equipment switches are outside the glovebox.

- Valves are outside the glovebox where possible.

- Remote temperature sensors don't need positioning.

- Mixing by machine where possible (previous cementing done by hand).

- Sphincter port was installed for product can and cement insertion.

- Commercial can opener speeds feed preparation.

- Maximum batch sizes are used where possible.

\section{Lower Dose Location Used}

- The area of highest dose is between HA-20MB and HA-21I near the conveyor. This area is avoided by grouping the equipment on the far side of HA-2OMB which is opposite HA-21I and at the end of the glovebox away from the conveyor.

- The lowest dose in the glovebox and surrounding area is near where the mixers/auger have been installed. Most of the operations are performed in this area.

- Shielding is on the most commonly used side of the glovebox (where most of the equipment is grouped).

Vault feed material retrieval operations, transfer to Room 235B, seal in of feed, and seal out of stabilized material have been stream lined to reduce dose to personnel.

\subsection{INDUSTRIAL SAFETY}

\subsubsection{Foaming}

The addition of the SS\&C to the water may be accompanied by foaming due to the reaction between calcium metal and the water. 
When the foaming material approaches the top of the reactor, the auger feed is stopped until the foaming has subsided or the foam may be scraped away to feed into a cement mixture.

\subsubsection{Jaw Crusher}

The guard/hopper prevents the operator's gloved fingers from entering the crusher during operation.

\subsubsection{Can Opener}

Leather gloves are worn over the glovebox gloves to prevent cuts from handling the sharp lid.

\subsection{EQUIPMENT SAFETY CLASS ANALYSIS}

It was determined that no System $71 \mathrm{H}$ components would be rated as safety class or safety significant equipment due to the following:

1) the remote possibility of hazardous chemicals or radionuclides being released offsite, and

2) the low probability of a fatality or serious injury to an individual or group of workers in any accident scenario of the SS\&C Cementation Process.

Items in the SS\&C Cementation Process in glovebox HA-20MB which have safety importance to protect individual facility workers are listed below.

\subsection{HA-2OMB OFF-GAS SYSTEM}

Item: E-4 System for Cementation process in HA-20MB.

DPI-2-HA2OMB and V-28311-25A

Basis: The E-4 system provides off-gas from the glovebox which removes flammable (hydrogen) off-gases that are produced during the reaction of the SS\&C with water and cement. The glovebox pressure is negative relative to room pressure to ensure contamination control. The differential pressure on the HA-2OMB north HEPA filter indicates that the filter and offgas are operating at the minimum flowrate of $20 \mathrm{cfm}$. 


\subsection{MIXER REACTOR \#1 HIGH TEMPERATURE SHUTOFF INTERLOCK}

Item: Temperature Elements (Thermocouples), High Temperature Switch, and Alarm Annunciator

TE-20MB-1, TE-20MB-2, TAS-20MB-1, TAS-20MB-2

Basis: The mixer reactor high temperature shutoff system ensures that excessive water vapor is not discharged to the ventilation ducts by stopping the feed auger. Also, if the calcium metal is not evenly dispersed in the feed, the temperature 1 imit/interlock will provide a way to stop the feed and allow the heat of reaction to be dispersed before continuing the process.

The key component of this system is the high temperature switch (TAS-2OMB-1). The switch monitors thermocouples located on the mixer reactor in the HA-20MB glovebox and alarms if one of the thermocouples exceeds the set point limit. Thermocouples for this system are important because they supply the high temperature interlock switch with information. The alarm annunciator is also important because it notifies the operator that the mixer reactor temperature is high and the feed auger needs to be stopped if the automatic shutoff has not done so. 


\subsection{REFERENCES}

1 WHC-SD-CP-TI-181, Criteria for Identification and Control of Equipment Necessary for Preservation of the Safety Envelope and Safe Operation of PFP,

2 PFD-Z-200-011, Sand. S7ag, and Crucible Cementation Process Flow Document, Stubbs, A. M., July 1996.

3 WHC-OSD-Z-184-00039, Sand, Slag \& Crucible Cementation Process PFP, Stubbs, A. M., October 1996.

4 20-160-060, Stabilization Cementation

5 WHC-SD-CP-SAR-021, Rev. 5. Plutonium Finishing Plant Final Safety Analysis Report (FSAR). Sudmann, R. H. 9/30/96.

6 PFP-96-007, Rev. 0. Cementation of Sand, S7ag, and Crucible Items in Glovebox HA-20MB. Funston, G. A. and Rodgers, L. H. 9/15/96.

7 CPS-2-165-80634, Sand, Slaq, and Crucible Cementation Process, Glovebox HA-20MB.

8 WHC-SD-SQA-CSA-513, Rev. 1. CSER-96-013: Cementation Process, Glovebox HA-2OMB.

9 WHC-SD-CP-FHA-004, Rev. 0, Fire Hazards Analysis for Plutonium Finishing Plant Complex. 


\section{APPENDIX A}

\section{SYSTEM DRAWING LIST}

\begin{tabular}{|c|c|}
\hline & SSEC CEMENTATIOH PROCESS IN GLOVEBOX HA-ZONB \\
\hline $\begin{array}{l}\text { Drawing } \\
\text { Number. }\end{array}$ & Title \\
\hline $\mathrm{H}-2-99536$ SH. 1 & HA-2OMB SS\&C CEMENTATION GLOVEBOX ARRANGEMENT \\
\hline $\mathrm{H}-2-99536$ SH. 2 & HA-2OMB SS\&C CEMENTATION GLOVEBOX ARRANGEMENT LAYOUTS \\
\hline $\mathrm{H}-2-99536$ SH. 3 & HA-2OMB SS\&C CEMENTATION GLOVEBOX ARRANGEMENT DIAGRAM \\
\hline $\mathrm{H}-2-99536 \mathrm{SH} .4$ & HA-2OMB SS\&C CEMENTATION GLOVEBOX ARRANGEMENT DIAGRAM \\
\hline $\mathrm{H}-2-96400 \mathrm{SH} .1$ & WASTE STABILIZATION CEMENTATION PROCESS WIRING DIAGRAM \\
\hline $\mathrm{H}-2-96400 \mathrm{SH} .2$ & WASTE STABILIZATION CEMENTATION PROCESS WIRING \\
\hline$H-2-96400$ SH. 3 & WASTE STABILIZATION CEMENTATION PROCESS WIRING \\
\hline $\mathrm{H}-2-825866 \mathrm{SH} .1$ & FIRE PROTECTION DRY CHEMICAL EXTINGUISHING SYSTEM, GLOVEBOX HA-2OMB \\
\hline
\end{tabular}


HNF-SD-CP-SDD-020

Rev. 0

\section{APPENDIX B}

\section{MASTER COMPONENT INDEX LIST SS\&C CEMENTATION PROCESS}

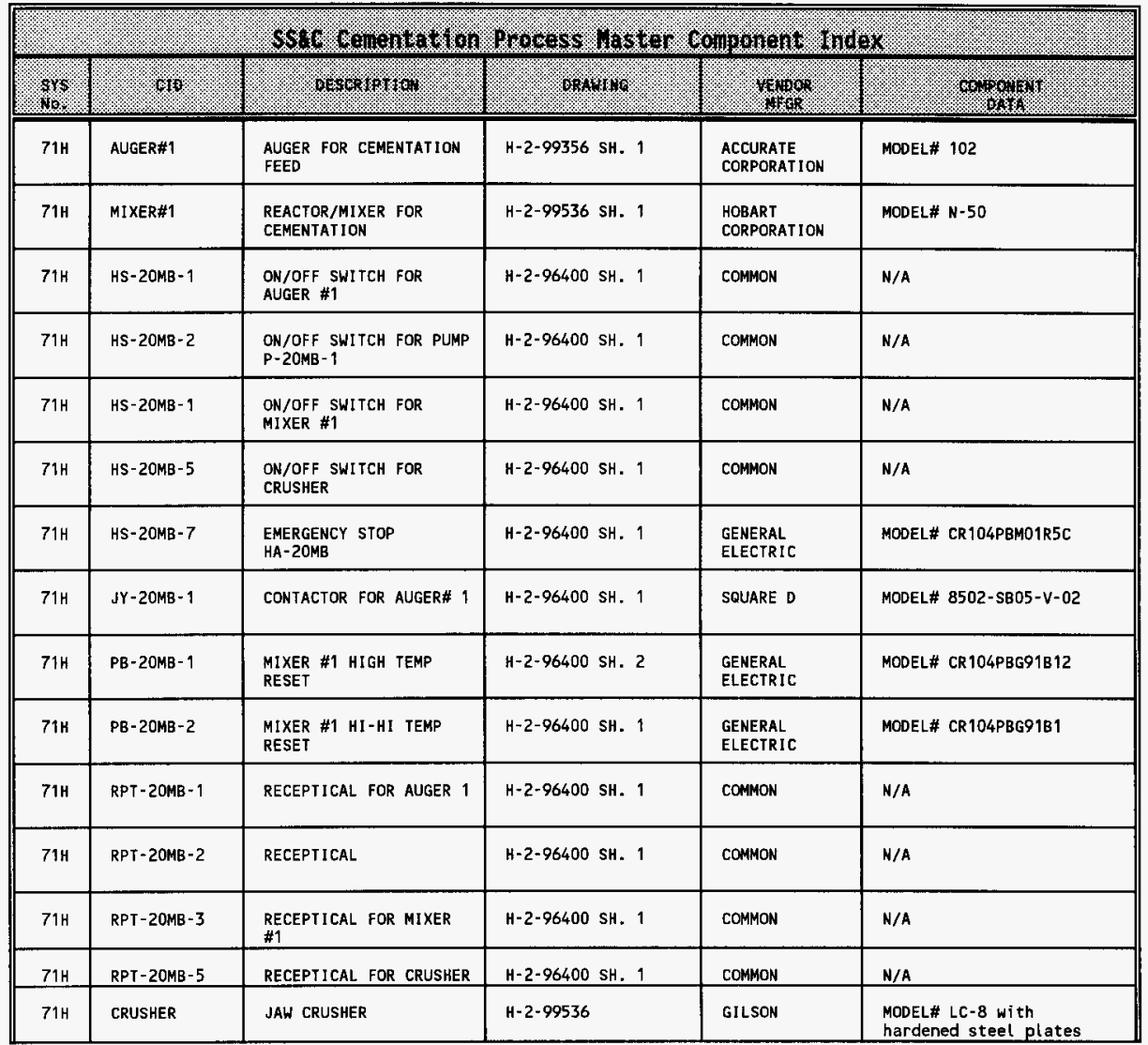


HNF-SD-CP-SDD-020
Rev. 0

\begin{tabular}{|c|c|c|c|c|c|}
\hline & & 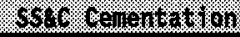 & 62008 . & 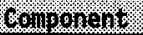 & Fols \\
\hline 10 & 4 & o & 0,40 & 20 & $60 \%$ Dow \\
\hline $71 \mathrm{H}$ & TAS - 20MB - 1 & $\begin{array}{l}\text { MIXER \#1 HIGH } \\
\text { TEMPERATURE ALARM }\end{array}$ & $\mathrm{H}-2-96400 \mathrm{SH} .1$ & EUROTHERM & MODEL\# 93/0/0/96651/A0 \\
\hline $71 \mathrm{H}$ & TAS-20MB-2 & $\begin{array}{l}\text { MIXER \#1 HI-HI TEMP. } \\
\text { ALARM }\end{array}$ & $\mathrm{H}-2-96400 \mathrm{SH} .1$ & EUROTHERM & MODEL\# $93 / 0 / 0 / 96651 / A 0$ \\
\hline $71 \mathrm{H}$ & $\mathrm{TC}-20 \mathrm{MB}-1$ & $\begin{array}{l}\text { THERMOCOUPLE MIXER \#1 } \\
\text { HIGH TEMP }\end{array}$ & $\mathrm{H}-2-96400 \mathrm{SH} .1$ & OMEGA & MODEL\# OS36-K-180F \\
\hline $71 \mathrm{H}$ & $\mathrm{TC}-20 \mathrm{MB}-2$ & $\begin{array}{l}\text { THERMOCOUPLE MIXER \#1 } \\
\text { HI-HI TEMP }\end{array}$ & H-2-96400 SH. 1 & OMEGA & MODEL\# OS36-K-180F \\
\hline $71 \mathrm{H}$ & WATERTANK & MAKEUP WATER TANK & $\mathrm{H}-2-99536$ & & \\
\hline $71 \mathrm{H}$ & CHILLER & RECIRCULATION CHILLER & $\mathrm{H}-2-99536$ & NESLAB & MODEL\# CFT SERIES R134a \\
\hline
\end{tabular}




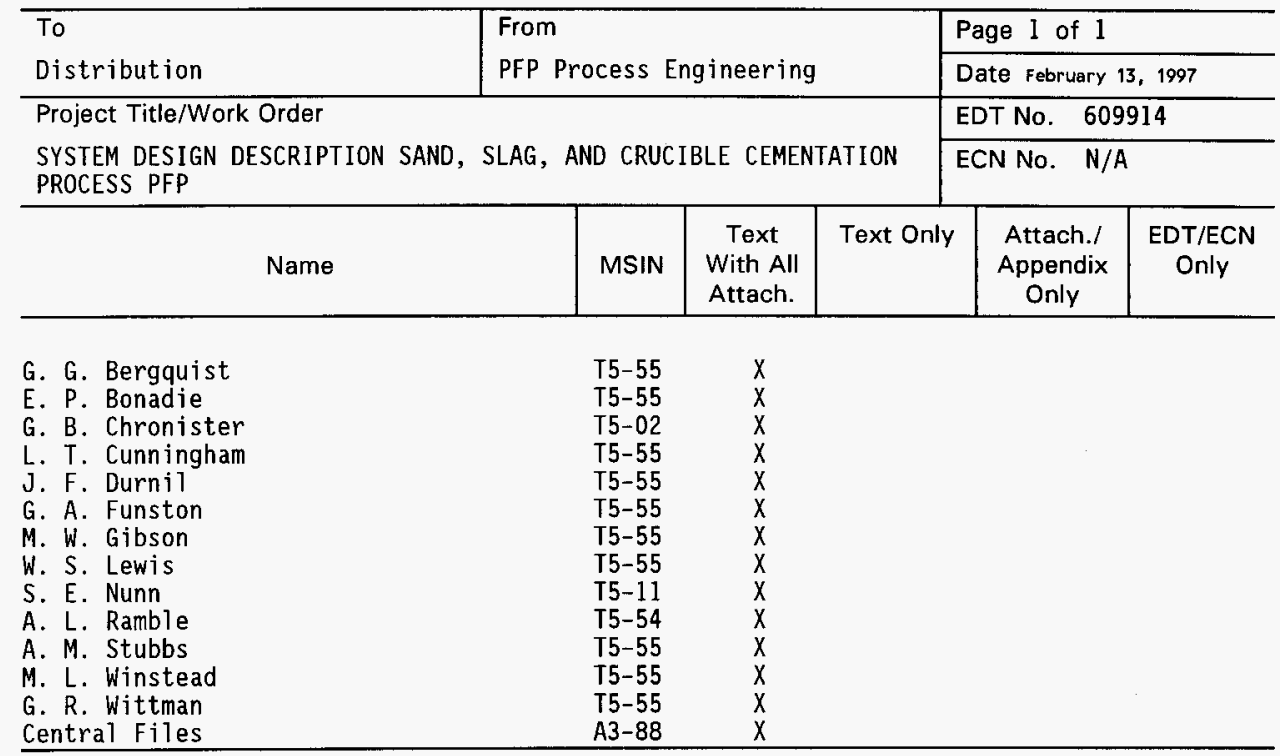

